\title{
TTR
}

Traduction, terminologie, rédaction

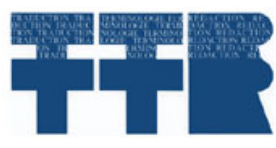

\section{Cultural Translation: Two Modes}

\section{Kyle Conway}

Volume 26, numéro 1, 1er semestre 2013

Traduction et contact multilingue

Translation and Multilingual

URI : https://id.erudit.org/iderudit/1036948ar

DOI : https://doi.org/10.7202/1036948ar

Aller au sommaire du numéro

\section{Éditeur(s)}

Association canadienne de traductologie

ISSN

0835-8443 (imprimé)

1708-2188 (numérique)

Découvrir la revue

Citer cet article

Conway, K. (2013). Cultural Translation: Two Modes. TTR, 26(1), 15-36.

https://doi.org/10.7202/1036948ar

\section{Résumé de l'article}

La présente contribution examine les raisons pour lesquelles les chercheurs qui proposent une réflexion théorique sur la traduction culturelle n'ont pas toujours été d'accord sur la nature même de leur objet d'étude. Deux définitions concurrentes sont analysées d'un point de vue diachronique, l'une provenant de l'anthropologie, l'autre, des « cultural studies ». L'article met en lumière trois facteurs qui viennent compliquer le débat sur la traduction culturelle : le fait que les anthropologues et les spécialistes des « cultural studies » ne partagent pas les mêmes présupposés épistémologiques et méthodologiques ; les rapports entre la langue, la culture et les textes, qui sont souvent ambigus et surchargés de connotations politiques ; une asymétrie d'usage. En guise de conclusion, l'auteur envisage les implications d'un point de convergence, à savoir le tournant éthique dans le contexte des débats sur les accommodements raisonnables en Amérique du Nord.
Ce document est protégé par la loi sur le droit d'auteur. L'utilisation des services d’Érudit (y compris la reproduction) est assujettie à sa politique d'utilisation que vous pouvez consulter en ligne.

https://apropos.erudit.org/fr/usagers/politique-dutilisation/ 


\title{
Cultural Translation: Two Modes
}

\author{
Kyle Conway \\ University of North Dakota
}

\begin{abstract}
This article examines why scholars who theorize cultural translation have not always agreed on what their object of study is. It provides a diachronic account of two competing definitions, one from anthropology and one from cultural studies. It also describes three factors that have complicated debates about cultural translation: the different epistemological and methodological assumptions made by anthropologists and cultural studies scholars; the ambiguous, politically charged relationships linking language, culture, and text; an asymmetry of usage. This article concludes by considering the implications of a point of convergence-the ethical turn taken in anthropology and cultural studies in the last two decades-for debates about attempts to ban Muslim veils from public spaces in North America.
\end{abstract}

\section{Résumé}

La présente contribution examine les raisons pour lesquelles les chercheurs qui proposent une réflexion théorique sur la traduction culturelle nont pas toujours été d'accord sur la nature même de leur objet d'étude. Deux définitions concurrentes sont analysées d'un point de vue diachronique, l'une provenant de l'anthropologie, l'autre, des «cultural studies». L'article met en lumière trois facteurs qui viennent compliquer le débat sur la traduction culturelle: le fait que les anthropologues et les spécialistes des «cultural studies» ne partagent pas les mêmes présupposés épistémologiques et méthodologiques; les rapports entre la langue, la culture et les textes, qui sont souvent ambigus et surchargés de connotations politiques; une asymétrie d'usage. En guise de conclusion, l'auteur envisage les implications d'un point de convergence, à savoir le tournant éthique dans le contexte des débats sur les accommodements raisonnables en Amérique du Nord.

Keywords: anthropology, cultural translation, cultural studies, ethical turn, reasonable accommodations

Mots-clés : anthropologie, traduction culturelle, «cultural studies», tournant éthique, voile musulman 
"Cultural translation," according to some, is a shibboleth. In the past two decades, it has become one of those concepts "that at a certain point in time achieve such a broad circulation that they seem able to name just by themselves the main determinants of the epoch" (Ribeiro, 2004,p. 2). As a result, it is also a term fraught with ambiguity, "one of those many terms [...] that have become so thick with inappropriate and incriminating meanings that we have to slough off these layers like dead skin every time we want to use them" (Jordan, 2002, p. 97). Part of the problem has to do with "culture," a term that "has continued to swim in the tide of intellectual fashion, leaving behind it an accumulating trail of discarded significances not unlike a pile of old clothes" (Ingold, 1993, p. 210). Part has to do with "translation," a term whose value is lost in "the theoreticism of the commentary" about cultural translation, which "preempts any close textual analysis" (Venuti, 2003 , p. 244). In either case, the problem seems to stem from the concern that "the constant expansion of the meaning of the term translation [...] threatens to drain it of its content and through this of its operability" (Guldin, 2003, p. 109).

So what is cultural translation, and how does it function? In the broadest possible sense, cultural translation is what happens when two semiotic systems-language or, more broadly, cultureas-interpretive-framework-come into contact. Debates about what cultural translation is or should be are really debates about the modes and consequences of this contact. Two camps distinguish themselves in these debates. On the one hand, anthropologists and ethnographers have historically treated cultural translation as the use of a domestic vocabulary to explain a foreign culture or cultural artifact. On the other, literary scholars, along with their translation studies and cultural studies counterparts, have spoken of cultural translation, first, as the lived experience of people displaced by migration, and second, more narrowly, as the reinscription of a foreign text in a new locale where its foreignness remains intact.

These debates and, consequently, definitions or conceptions of cultural translation are complicated by three things. First, they are complicated by the different epistemological and methodological assumptions made by the members of the disciplines staking claim to the term. Second, they are complicated by the ambiguous, 
politically charged relationships linking language, culture, and text. Finally, they are complicated by a certain asymmetry of usage: anthropologists and ethnographers have been more willing to consider both translational modes than their counterparts in literature, translation, and cultural studies.

In this article, I describe the two dominant modes of cultural translation by examining how debates about the term have played out historically, considering each of the three complicating factors in turn. To be clear, my purpose is not to provide a genealogy of these ideas. Such a task would exceed the limits of an article because of the need to account for the "broader history of the intellectual and cultural traditions that shape those disciplines" where ideas of cultural translation have been employed (D'hulst, 2010 , p. 254). Instead, I provide the beginning of an explanation for why people discussing "cultural translation" have not seen eyeto-eye. This diachronic view complements the synchronic view I provide elsewhere (see Conway, 2012a) and is meant to improve the term's conceptual clarity.

I conclude this article by examining one point where the two modes converge, namely the question of the ethical encounter with alterity. To illustrate, I consider two recent events in Quebec history, the release of the report of the Consultation Commission on Accommodation Practices Related to Cultural Differences (see Bouchard and Taylor, 2008) and the tabling in Quebec's legislature of Bill 94, An Act to Establish Guidelines Governing Accommodation Requests Within the Administration and Certain Institutions. The first represented an attempt to clear space for religious "others" in Quebec, while the second represented a partial foreclosure of that gesture's radical potential. As the historical examination and case study demonstrate, notions of cultural translation can provide useful conceptual tools for describing the circulation of people, ideas, and texts through different national, linguistic, and cultural locales, and for framing questions of ethics in a globalized world.

\section{Anthropology and Its Interlocutors}

Two different senses of "translation" underpin notions of "cultural translation": rewriting and transposition. Cultural translation as rewriting emphasizes the text that is produced when someone explains to members of one cultural community how members of 
another see the world. Historically, its practitioners treated culture as a framework of signs for which they could substitute other signs. They assumed that language functioned like a system of containers: words in different languages carried the same semiotic contents, which is to say, the world as described by language. Because the semiotic contents remained the same, foreign texts and cultures were inherently legible to domestic readers. In recent years, however, as this section describes, practitioners of cultural translation in this sense have come to question many of these assumptions.

Cultural translation as transposition refers more to movement than writing, much as in math, where "translation" refers to the repetition of a geometric shape without alteration at a new set of coordinates. What makes this movement interesting is the transformation it brings about, especially within a cultural community as its members come into contact with cultural "others." In contrast to translation as rewriting, notions of translation as transposition are informed by the assumption that the foreign text or culture is not immediately legible to the domestic reader.

I want to emphasize that the value of this distinction is heuristic: it provides a shorthand for naming sets of assumptions that frequently go together. This schematic presentation betrays the messiness of the term's use in real life: people within the same discipline often bring contradictory assumptions to bear in their discussions of cultural translation, and their conceptions evolve over time.

This messiness is visible in social and cultural anthropology, which has had cultural translation at its heart since the 1950s. Early in the decade, for instance, Godfrey Lienhardt delivered a lecture on $\mathrm{BBC}$ radio where he explained, "The problem of describing to others how members of a remote tribe think [...] begins to appear largely as one of translation, of making the coherence primitive thought has in the languages it really lives in, as clear as possible in our own" (1954, p. 97). A few years later, Ernest Gellner described the anthropologist's task in similar terms in an address to the Conference of the Society for the Philosophy of Science:

The situation, facing a social anthropologist who wishes to interpret a concept, assertion or doctrine in an alien culture, 
is basically simple. He is, say, faced with an assertion $S$ in the local language. He has at his disposal the large or infinite set of possible sentences in his own language. His task is to locate the nearest equivalent or equivalents of $S$ in his own language. (1970 [1958], p. 24)

The methods of cultural translation have followed from its practitioners' epistemological assumptions, which have evolved considerably during the last half century. Anthropologists beginning with Lienhardt, Gellner, and their contemporaries used the word culture to describe two things. In the abstract, culture referred to "the sum total of what an individual acquires from his society-those beliefs, customs, artistic norms, food-habits and crafts which come to him not by his own creative efforts but as a legacy from the past" (Robert Lowie, cited in Ingold, 1993, p. 211). On the other hand, a culture (in the particular) was the discrete community or group whose members drew on their shared "beliefs, customs, artistic norms, food-habits and crafts" in order to interpret the world around them. This dual conception of culture was apparent, among other places, in the hermeneutical terms anthropologists employed when describing the steps involved in cultural translation: to understand a culture, the anthropologist had to step into that culture and see the world from within the interpretive horizon provided by its beliefs, customs, and so on. For example, "In order to understand what witchcraft means to them [in this case, the Azande in central Africa] we have to start, as in assenting to anyone's thought, by making one or two assumptions which they make" (Lienhardt, 1954, p. 99). Or, in Gellner's words, "concepts and beliefs do not exist in isolation, in texts or in individual minds, but in the life of men and societies. The activities and institutions, in the context of which a word or phrase or set of phrases is used, must be known before that word or those phrases can be understood, before we can really speak of a concept or a belief" (1970 [1958], p. 22).

Cultural translation in this sense was not without contradictions, however. Gellner, for instance, raised the thorny issue of dealing with apparent contradictions in the culture being described. If the goal of cultural translation was to re-express foreign ideas in a domestic idiom, how should anthropologists express ideas that appeared absurd or paradoxical? Should they 
assume that these ideas made sense in the culture they were describing, or should they assume they were nonsensical? How could they tell the difference?

In more recent decades, anthropologists have taken a closer look at these contradictions and, more importantly, the implications of how their discipline has dealt with them. As more than a few have demonstrated (see James and Marcus, 1986; Niranjana, 1992; Said, 1989), the approach that anthropologists take to dealing with such contradictions can be read as an index of the power relations between them and their interlocutors: the status of the anthropologist's language relative to that of the interlocutor's is an important factor in determining which language bends or yields, and the domesticating approach adopted by people like Lienhardt and Gellner is symptomatic of the assumption that a foreign culture is legible to the Western anthropologist (see Asad, 1986).

Tejaswini Niranjana offers an extreme example of this assumption in her description of William Jones, an eighteenth century British jurist whose goal was "to know India better than any other European knew it" (cited in Niranjana, 1992, p. 12). In his work, as Niranjana describes it, Jones focused on "(a) the need for translation by the European, since the natives are unreliable interpreters of their own laws and culture; (b) the desire to be a lawgiver, to give Indians their 'own' laws; and (c) the desire to 'purify' Indian culture and speak on its behalf” (ibid., p. 13). Not all anthropologists have gone to this length, of course. However, as critics like Vincent Crapanzano and Edward Said argue, the very act of turning a culture into a text is an assertion of authority not unlike Jones's. To produce an article or a monograph, anthropologists engage in an act of cultural translation that also entails translation from one language to another and from oral forms to written forms of language. They are faced with a paradox in that they must "render the foreign familiar and preserve its very foreignness at one and the same time," a task for which they employ various rhetorical strategies, which in turn shore up their institutional, academic claim to authority (Crapanzano, 1986, pp. 52-53). Even more insidious, according to Said, is the way in which the authority they invest in written texts, at the expense of oral texts, drowns out the 
clamor of voices on the outside asking for their claims about empire and domination to be considered. The native point of view, despite the way it has often been portrayed, is not an ethnographic fact only, is not a hermeneutical construct primarily or even principally; it is in large measure a continuing, protracted, and sustained adversarial resistance to the discipline and the praxis of anthropology [...]. (1989, pp. 219-220)

In this way, anthropologists working within a postcolonial framework have rejected the epistemological assumptions of their predecessors, in particular their assumptions about the nature of "culture" (in the abstract) and "cultures" (in the particular), as well as the textual approaches that followed from those assumptions. For some, such as Tim Ingold (1993), that rejection is absolute: to divide the world up into discrete cultures, he argues, is to impose boundaries where in fact there is only a continuum of difference. Others stop short of Ingold's position but still adopt a more reflexive set of assumptions as well as an approach to writing that works to draw their own authority into question. At the level of translation between languages, Talal Asad addresses what he calls the "inequality of languages" by advocating approaches that "test the tolerance of [the anthropologist's] own language for assuming unaccustomed forms" (1986, p. 157). At the level of cultural translation, Shirley Ann Jordan takes a related tack: "To produce cultural translation is not a question of replacing text with text," she writes, "but of co-creating text, of producing a written version of a lived reality, and it is in this sense that it can be powerfully transformative for those who take part" (2002, p. 98; my italics), which is to say, anthropologists.

Contemporary notions of "cultural translation" within anthropology, then, reflect the term's contested nature following the troubled history of its use. The epistemological assumptions of people like Lienhardt and Gellner, namely that they could understand cultures as discrete groups with knowable frameworks for interpreting the world, have given way to a set of assumptions about the need to turn the anthropologist's focus back on the discipline itself. Likewise, the hermeneutical methods employed by Lienhardt and Gellner have given way to more reflexive methods that acknowledge the historical conditions-shot through with 
complex power relations linking language, culture, and the texts anthropologists produce - in which cultural translation has taken place. Thus, anthropologists' early emphasis on domesticating approaches, where they worked to describe a foreign culture in Western terms, has now been largely replaced by its opposite, an emphasis on foreignizing approaches that test the limits of the language they share with their readers. In this way, anthropologists have revised what they mean by cultural translation: although they still emphasize the text they produce, their epistemological assumptions have converged with those of people who treat cultural translation as a form of transposition, as described in the next section.

\section{Cultural Translation as Cultural "Carrying-Across"}

Conceptions of cultural translation as transposition have grown out of three relatively independent but closely related fields: literary studies, translation studies, and cultural studies. Remarkably, despite apparent affinities with anthropology, scholars from these three fields rarely mention anthropology when discussing the historical development of cultural translation (see, e.g., Simon, 1995, 1997; Trivedi, 2007; for a counter-example, see Bery, 2010).

The development of notions of cultural translation within these fields has been messier than the corresponding development within anthropology, largely because of the intertwined and contested histories of the disciplines themselves. Notions of cultural translation in these disciplines came about because of a convergence of interests that took place only in the 1990s, even though the roots of the different fields themselves reach further back. According to Terry Eagleton, what the Englishspeaking world now recognizes as the discipline of literary studies dates back to the late $19^{\text {th }}$ century when literature in Victorian England gained prominence as a potential cure for the social ills associated with industrialization (1983, pp.17-53). Although literary scholars were concerned with translation on a practical level, translation studies would not emerge as a distinct discipline until the 1970s. In 1975, George Steiner, focusing largely on literature, published After Babel, one of the first sustained efforts to theorize translation. In 1976, scholars such as Itamar EvenZohar and André Lefevere gathered in Leuven, Belgium, for 
the symposium "Literature and Translation: New Perspectives in Literary Studies," which Susan Bassnett cites as a turning point in the establishment of translation studies as a discipline in its own right (1998, p. 124). Even-Zohar and other like-minded scholars brought an identifiably linguistic bent to their approach, meaning that translation studies in its early days had two disciplinary sources: literature and linguistics.

Cultural studies took root in British literature departments in the 1950s. Stuart Hall cites two works that helped "stake out the new terrain": Richard Hoggart's The Uses of Literacy, published in 1957, and Raymond Williams's Culture and Society, published in 1958, both of which challenged the subordination of working class culture to Culture-with-a-capital-c (1980, p. 57). Following in this vein, early cultural studies scholars, in particular those working at the Centre for Contemporary Cultural Studies at the University of Birmingham, approached culture as a site of struggle for the production of meaning. As cultural studies spread to the United States, Canada, and Australia in the 1970s and 1980s, its practitioners began to apply structuralist frameworks to questions of culture in order to tease out the power relations that characterized a given society (see Hall, 1980).

Cultural studies scholars turned their attention to questions of translation only in the 1990s when, borrowing insights from poststructuralism and postcolonial literary studies, they began to investigate the ways that language and culture are mutually constitutive. At roughly the same time, translation studies scholars began moving away from literary and linguistic models, whose mode of inquiry consisted in comparing originals and their translations and asking questions related to equivalence, and shifted their attention toward questions of culture, especially the roles played by authors, translators, and the texts they produce in their respective cultures (see Bassnett and Lefevere, 1990). Despite an apparent congruence of interests, however, cultural studies and translation studies, operating from different epistemological assumptions, never really converged. Translation studies, especially in its first decades, treated culture as a set of practices and assumptions constituting a shared interpretive framework, in ways similar to anthropology. Texts such as literary or technical documents were (and continue to be) a central focus. On the other 
hand, cultural studies, since its inception, has treated culture as a site of negotiation and a product of struggle or contestation. Texts, in the sense of discrete documents, have played a less prominent role.

Because of their divergent focuses (equivalence on the one hand, alterity and contestation on the other) and their divergent approaches to texts, these two disciplines have dealt with translation in very different ways. Cultural studies scholars have drawn heavily on theorists like Homi Bhabha (1994) who look to the etymological roots of the word translate-from the Latin, meaning "to carry across"-for their understanding of cultural translation. In contrast to their counterparts in translation studies, then, cultural studies scholars have treated translation as a form of transposition rather than rewriting. In this respect, one of Bhabha's principal inspirations, Salman Rushdie's (1988) novel The Satanic Verses, opens with an illustrative image: a plane bound for London is blown up in the skies over the English Channel, and the two Indian protagonists fall to earth. In other words, in their descent, they are translated into Britain and British culture.

The appeal that cultural translation in this sense holds for cultural studies scholars is its apparent potential to be one mechanism by which "newness enters the world," to paraphrase Bhabha's reading of Rushdie. By this, Bhabha means that the introduction of a foreign element into a domestic context destabilizes notions of both "foreign" and "domestic," especially in multicultural, postcolonial societies such as Britain, whose narratives of cultural homogeneity presuppose and reinforce artificially clear distinctions between Europe and its former colonies. The linguistic and cultural disjunctures brought about or made manifest by cultural translation challenge a community's received sense of itself by drawing those very distinctions into question, opening up a space for something new to emerge (Bhabha, 1994, pp. 212-235).

Like Bhabha, António Sousa Ribeiro sees cultural translation as having the potential to interrupt the logics of hegemonic culture. In particular, he argues that it can serve as a means to resist the homogenizing, colonizing tendencies of globalization: 
[I]f we can think of hegemonic globalization as globalization without translation, the very idea of a counter-hegemonic globalization is totally dependent on a notion of translation, since it has by definition to be critical of any centralism or universalism and cannot rely on any transcendental principle, but, instead, has to go along through providing the means for the articulation of cultures and intercultural interchange. (2004, p. 3)

Tomislav Longinovic, for his part, looks at micro-instances of cultural translation. For him, cultural translators are "the legal and illegal immigrants, refugees, asylum-seekers as well as itinerant academics" who come to understand their identities through their displacement and the resulting experience of alterity (Longinovic, 2002, pp. 6-7). Longinovic shares Bhabha's hope about cultural translation's utopian potential: "The impossibility of absolute sameness in translation, he writes, opens a horizon for a new performance of cultural identity as a process of dynamic exchange between semiotic registers motivated by non-hierarchical openness and movements of meaning and identity"(ibid., pp. 7-8). However, this hope is held in check by the fact that immigrants, refugees, and asylum-seekers occupy a subaltern position where their is agency limited by the "double bind of global inequality, or fearful asymmetry, in the rate and value of minor culture's representation" (ibid., p. 6).

One result of this emphasis on subaltern groups has been that until recently cultural studies scholars have not articulated a clear method for "doing" cultural translation. "Method" in a socialscientific sense would be largely nonsensical: because cultural translators occupy a subaltern position, where they are subject to the vicissitudes of a cultural logic that is not their own, their acts of cultural translation are necessarily contingent and cannot be theorized from any a priori assumptions (see Longinovic and Buden, 2008). However, a debate in 2009 and 2010 in the journal Translation Studies raised the issue of how ideas of cultural translation might influence people to act. Boris Buden and Stefan Nowotny (2009) open the debate by considering cultural translation from the perspective of people occupying positions of power (in contrast to Bhabha, Ribeiro, and Longinovic). They cite a poem by Bertolt Brecht about a man applying for U.S. 
citizenship. In that poem, the man provided the same wrong answer- "1492" - to every question he is asked. After three questions, "The judge, who liked the man, realised that he could not/Learn the new language, asked him/How he earned his living and was told: by hard work" (Brecht, cited in Buden and Nowotny, 2009, pp. 206-207). In an act of compassion, the judge then asked when Columbus discovered America, at which point the man's answer was correct. Buden and Nowotny argue that the judge posed the correct question to a wrong answer, which leads them to ask, "is 'democracy' simply a wrong answer still waiting for a correct question? The search for this question, and nothing else, is cultural translation" (ibid., p. 207). Cultural translation, in their view, involves acts of hospitality and cannot be separated from the ethical dimension of people's encounter with cultural "others." Our actions may be constrained by social and political forces, but can we negotiate a way to open a space for the "other"? If so, how?

\section{Interculturalism and Cultural Translation}

It is at this point that notions of cultural translation as rewriting and transposition are converging. Practitioners of both are reflexive in their encounter with the "other," their goal being to avoid reproducing historical relationships of dominance. In other words, they both work to clear a space for "others" to operate on their own terms, rather than terms imposed by people occupying a position of hegemony. They do this by turning their attention back on themselves, in dialogue with the "other."

Consequently, notions of cultural translation as rewriting and transposition provide complementary lenses through which to observe the dynamics of culture in multicultural, multilingual societies. I will offer one example here, that of Quebec, whose government and citizens have actively addressed questions of identity and hospitality in the past decade, especially in response to the reasonable accommodation controversy of the mid2000s. ${ }^{1}$ One response to the controversy was to acknowledge that

1. These notions are complementary in more ways than what I describe here. Elsewhere I discuss how they provide analytical insights into journalists' efforts to explain (through a form of rewriting) how immigrants, transposed into a new cultural milieu, understand the new place they occupy (Conway, 2012a, pp. 272276). 
Quebecers themselves, and not just recent immigrants or members of religious minorities, would need to adapt to the province's changing demographics. This response represented an attempt to clear a space for religious "others": it posed a "correct question" to what many saw as a "wrong answer." A second response, the tabling of a bill that would restrict Muslim women's ability to wear head-coverings in specific circumstances, represented a partial foreclosure of the potential of this act of hospitality. The implications of the bill were complex, and many supported it as a way to support Muslim women. But many supported it because they thought they knew better than the women affected what certain head-coverings meant: Islam, as they saw it, was inherently legible and available for their scrutiny.

\section{Reasonable Accommodations: The Bouchard-Taylor Report}

In February 2007, many Quebecers of European descent were concerned about what they saw as special treatment being accorded to recent immigrants and members of cultural minorities. In response, Quebec premier Jean Charest launched the Consultation Commission on Accommodation Practices Related to Cultural Differences. Researchers led by sociologist Gérard Bouchard and philosopher Charles Taylor then commissioned more than a dozen research projects, held nearly sixty meetings with experts and representatives of different social and cultural organizations, held public consultations across the province, and operated a website to solicit feedback from as wide a range of Quebecers as possible (Bouchard and Taylor, 2008, pp. 8-9).

Broadly speaking, the commission's mandate was to take stock of reasonable accommodation practices-that is, actions taken by the government and by private groups to accommodate minority religious or cultural preferences - in the province. While the idea of reasonable accommodation "stems from jurisprudence in the realm of labour" and "indicates a form of arrangement or relaxation aimed at ensuring respect for the right to equality," by the mid-2000s, "the meaning of the concept [had] gone beyond this legal definition and encompasse[d] all forms of arrangements allowed by managers in public or private institutions in respect of students, patients, customers, and so on" (Bouchard and Taylor, 2008, p.7). A large percentage of Francophone Quebecers- 
almost three quarters (ibid., p. 22)—were concerned that members of religious minorities, especially but not exclusively Muslims, were requesting undue accommodations that threatened traditional Québécois values, of which two were especially important. First was the province's hard-won secularism, the product of the nationalist project begun in the 1960s, which grew in part out of the desire to reduce the long-standing influence of the Catholic Church. Second was the presumption of gender equality that developed as Quebec grew more secular. Many Quebecers saw these values as linked: if secularism was imperiled, so was gender equality.

For example, many people thought that the Société de l'assurance automobile du Québec (SAAQ), which issues drivers' licenses, was granting requests for examiners of one sex rather than the other, depending on the religious rules followed by the person making the request. Bouchard and Taylor emphasized, however, that "[i]f we can speak of an 'accommodation crisis,' it is essentially from the standpoint of perceptions" $(2008$, p. 13). Where the SAAQ was concerned, for instance, the official policy was to grant requests for an examiner of a specific sex only if one was available, and otherwise to reschedule. They argued instead that Quebecers' apprehension could be traced back to multiple origins, including lingering questions about the nature of the changes undergone by Quebec society since the 1970s and a "social context permeated by suspicion and insecurity" in wake of the events of 11 September 2001 (ibid., p. 14; see also Conway, 2012b).

In their report, Bouchard and Taylor built on ideas related to Quebec's official but unwritten policy of interculturalism, by which policy-makers hoped to encourage integration while maintaining respect for immigrants' culture of origin. Because the policy "seeks to reconcile ethnocultural diversity with the continuity of the French-speaking core and the preservation of the social link," it institutes French as the "common public language," thereby "establish[ing] a framework in society for communication and exchanges. It has the virtue of being flexible and receptive to negotiation, adaptation and innovation" $(2008$, p. 40). In this light, Bouchard and Taylor made a series of recommendations that included a call to define policies of interculturalism explicitly, 
to make it easier for immigrants to have their foreign credentials recognized and to find jobs, to train public officials for intercultural competence, and to fight discrimination (ibid., pp. 91-92).

One way in which the Quebec government has responded has been through Bill 94, An Act to Establish Guidelines Governing Accommodation Requests within the Administration and Certain Institutions, introduced by Justice Minister Kathleen Weil in March 2010. ${ }^{2}$ As its title suggests, its purpose was to codify the policy of reasonable accommodations, at least within specific circumstances. It defined "accommodation" as an "adaptation of a norm or general practice, dictated by the right to equality, in order to grant different treatment to a person who would otherwise be adversely affected by the application of that norm or practice" (Government of Quebec, 2010, sec. 1). It defined "reasonable" as "not impos[ing] on the department, body or institution [from which an accommodation is requested] any undue hardship [...]" (ibid., sec. 5). Its most controversial clause stated, "The practice whereby a personnel member of the Administration or an institution and a person to whom services are being provided by the Administration or the institution show their face during the delivery of services is a general practice" (ibid., sec. 6).

\section{Cultural Translation and Notions of Hospitality}

The reasonable accommodation controversy and Bill 94 have attracted considerable academic interest, with most scholars offering descriptive or normative discussions of the implications for women's rights or for Quebecers' sense of national identity (see Conway, 2012b; Hong, 2011; Ogrodnick, 2010; SharifyFunk, 2011). They tend to focus on the nature of the relationships between men and women or between Muslims and non-Muslims. Notions of cultural translation make it possible to go beyond such discussions by identifying the foundations of these relationships and uncovering the unspoken, culturally specific assumptions in which they are grounded. They force us to recognize the contingent nature of interactions between people who do not necessarily share a common set of cultural norms.

2. The bill was approved in principle in February 2011 and referred to Quebec's Committee on Institutions. 
What exactly does this approach yield? Bouchard and Taylor act on notions of hospitality in two ways. Their first move is reflexive: they turn their sights on Québécois culture itself, examining not the people requesting accommodations but Quebecers themselves. They offer an explanation of the controversy that looks to Quebec's recent history, rather than the (perceived) actions of religious minorities, and reveal the relations of power shaping interactions between majority and minority Quebecers.

The question of power plays a role in their second move. In their discussion of interculturalism, Bouchard and Taylor make eleven proposals to "allow us to define Québec interculturalism even more precisely" (2008, p. 40). The second and third bear mentioning here:

2. In a spirit of reciprocity, interculturalism strongly emphasizes interaction, in particular intercommunity action, with a view to overcoming stereotypes and defusing fear or rejection of the Other, taking advantage of the enrichment that stems from diversity, and benefiting from social cohesion.

3. Members of the majority ethnocultural group,i.e. Quebecers of French-Canadian origin, like the members of ethnocultural minorities, accept that their culture will be transformed sooner or later through interaction. (ibid., pp. 40-41)

In other words, they argue, not only is it the case that Quebecers cannot expect to force immigrants to conform to Quebec culture, but they must also recognize that

[c]onstant interaction between citizens of different origins leads to the development of a new identity and a new culture. This is what has been happening in Québec in recent decades without altering the cultural position of the majority group or infringing on the culture of minority groups. (ibid., p. 42)

To borrow from Buden and Nowotny, what Bouchard and Taylor ask Quebecers to do is to seek the "correct question" (i.e., a way to open a space for cultural "others") to what looks like a "wrong answer" (i.e., a failure to conform to the norms of Quebecers of European descent).

Such proposals make many Quebecers (and Canadians) nervous. They worry that they encourage an "anything goes" 
form of cultural relativism that threatens women's rights. Margaret Ogrodnick, for example, asserts that women's participation in politics (and the public sphere more broadly) is a "universal good, one that is not subject to cultural variation on the role and place of women" (2010, p. 36). She adds, "attitudes and practices in subcultures that impede this goal [of increased women's political participation] are not entitled to the value that might otherwise be attached to cultural diversity" (ibid., p. 38). ${ }^{3}$

It was in this spirit that Justice Minister Weil introduced Bill 94 in 2010. As the bill's preamble stated, "all accommodations are made subject to the Charter of human rights and freedoms, in particular as concerns the right to gender equality and the principle of religious neutrality of the State" (Government of Quebec, 2010, explanatory notes; my italics). On the one hand, the bill's goals were lofty: to eliminate discrimination and protect the shared values of equality and respect. On the other, the means by which they were to be achieved had a perverse effect: the bill "would prevent women wearing the niqab [face veil] from accessing hospitals, daycares, schools, universities, and other public services, and would bar women in niqab from working in the public sector" (Simone de Beauvoir Institute, 2010, p. 1). In other words, despite the intent by its authors to ensure a space for all women in the public arena, Bill 94 moved away from the mutual adaptation proposed by Bouchard and Taylor, foreclosing on the potential of hospitality, at least in part.

The idea that accommodating people (especially Muslim women) for religious reasons was incompatible with the value of gender equality was clear in the briefs in support of the bill that different groups submitted to Quebec's legislature. The Association des retraitées et retraités de l'éducation et des autres services publics du Québec, for example, was clear in equating face veils unambiguously with oppression. Others allowed for more

3. Ogrodnick also points out that her analysis coalesces with that of Bouchard and Taylor in its emphasis on the "value of gender equality," which led the commissioners to "recommend that the Quebec Charter [of Human Rights and Freedoms] be amended to include 'an interpretive clause that establishes gender equality as a core value of our society" (2010, p.44). In this respect, she also identifies a productive tension between the call for adaptation and the rootedness of Quebec society in specific cultural values. 
ambiguity. For instance, Laval University's Groupe de professeures associées à $\mathrm{La}$ Chaire Claire-Bonenfant called the full veil a "portable prison" while still acknowledging the "strong dissension among Muslim women here and abroad [...] concerning the meaning of different types of veils [...]," ultimately reaching no conclusion about the "real decisional capacity" for women choosing to wear the veil within a religious community that treats them (in the Groupe's view) as objects. The Confédération des syndicats nationaux allowed for similar ambiguity but ultimately decided that the veil was "an important symbol of women's submission or the requirements imposed on women but not on men." The fact that some saw such ideas as symptomatic of a greater power play was clear in the brief submitted by the Fédération des Canadiens Musulmans, which argued that Western feminists should not impose their notions of equality on "all the women on the planet. Instead of speaking on behalf of women wearing the niqab, it would be better to allow them to speak so that they themselves might describe their reality and explain their choices." (See Conway, 2012b for full examination of these briefs.)

Thus, many supporters of the bill asserted (without saying so explicitly) that they knew better than women who chose to wear a veil what that veil meant. Such an assertion was made possible by their implicit sense that Islam as a system of signs and symbols was legible to them: the veil meant what it meant-i.e., oppressionregardless of the situation in which it was interpreted.

\section{Conclusion}

This example provides a sense of the complementary analytical value of the two modes of cultural translation I have identified here. They allow us to identify the underlying assumptions about the relationship between cultural communities that come into contact with each other. This example also suggests that questions of hospitality are more complex than they might first appear. The impulse behind Bill 94 was positive: its authors wanted to ensure the continued respect for gender equality, in particular the rights of women to act without social or religious constraints. But it also reproduced the very attitude it hoped to counter, namely the idea that certain members of a community could tell others how to comport themselves. 
This article opened with the idea that some people see "cultural translation" as a shibboleth, a term (according to its critics) that serves not to clarify our understanding of the world but to signal a scholar's adherence to a certain school of thought, at the risk of expanding ideas of "translation" to a point of absurdity. If I have demonstrated anything, I hope it is that ambiguity surrounding ideas of cultural translation results not from a cynical desire to mark academic territory but from a series of intertwined, intersecting disciplinary histories whose complexity this article has begun to uncover. Questions of translation, hospitality, and the ethics of the encounter with alterity are some of the most pressing questions for understanding multiculturalism and translation in contemporary society. They address issues of immigration, governmental policy, and the media. They demand careful, theoretically informed, empirical investigation of the social and historical circumstances that shape contemporary society. Translation studies and cultural studies, making use of the distinctions between modes of cultural translation outlined in this article, are especially well positioned to offer answers to these questions and, from there, new insight into the dynamic relations shaping multicultural societies in our increasingly global world.

\section{References}

ASAD, Talal (1986). "The Concept of Cultural Translation in British Cultural Anthropology." In C. James and G.E. Marcus, eds. Writing Culture: The Poetics and Politics of Ethnography. Berkeley, University of California Press, pp. 141-164.

BASSNETT, Susan (1998). "The Translation Turn in Cultural Studies." In S. Bassnett and A. Lefevere, eds. Constructing Cultures: Essays on Literary Translation. Philadelphia, Multilingual Matters, pp.123140.

BASSNETT, Susan and André LEFEVERE (1990). "Proust's Grandmother and the Thousand and One Nights: The 'Cultural Turn' in Translation Studies.” In S. Bassnett and A. Lefevere, eds. Translation, History and Culture. New York, Pinter, pp. 1-13.

BERY, Ashok (2009). “Response.” Translation Studies, 2, 2, pp. 213-216. BHABHA, Homi K. (1994). The Location of Culture. New York, Routledge. 
BOUCHARD, Gérard and Charles TAYLOR (2008). Building the Future: A Time for Reconciliation (Abridged Report). Quebec City, Commission de consultation sur les pratiques d'accommodement reliées aux différences culturelles.

BUDEN, Boris and Stefan NOWOTNY (2009). "Cultural Translation: An Introduction to the Problem." Translation Studies, 2, 2, pp. 196208.

CONWAY, Kyle (2012a). "A Conceptual and Empirical Approach to Cultural Translation.” Translation Studies, 5, 3, pp. 264-279.

CONWAY, Kyle (2012b). "Quebec's Bill 94: What's 'Reasonable'? What's 'Accommodation'? And What's the Meaning of the Muslim Veil?" American Review of Canadian Studies, 42, 2, pp. 195-209.

CRAPANZANO, Vincent (1986). "Hermes' Dilemma: The Making of Subversion in Ethnographic Description." In C. James and G.E. Marcus, eds. Writing Culture: The Poetics and Politics of Ethnography. Berkeley, University of California Press, pp. 51-76.

D’HULST, Lieven (2010). “Response.” Translation Studies, 3, 3, pp. 353356.

EAGLETON, Terry (1983). Literary Theory: An Introduction. Minneapolis, University of Minneapolis Press.

GELLNER,Ernest (1970 [1958]).“Concepts in Society.”In B.R. Wilson, ed., Rationality. New York, Harper and Row, pp. 18-49.

Government of Quebec (2010). Bill 94: An Act to Establish Guidelines Governing Accommodation Requests within the Administration and Certain Institutions. [http://www.assnat.qc.ca/en/travauxparlementaires/projets-loi/projet-loi-94-39-1.html].

GULDIN, Rainer (2003). “The (Un)translatability of Cultures.” Studies in Communication Sciences, 3, 2, pp. 109-134.

HALL, Stuart (1980). "Cultural Studies: Two Paradigms.” Media, Culture and Society, 2, pp. 57-72.

HONG, Caylee (2011). "Feminists on the Freedom of Religion: Responses to Québec's Proposed Bill 94.” Journal of Law and Equality, 8, pp. 27-62.

INGOLD, Tim (1993). "The Art of Translation in a Continuous World.” In G. Pálsson, ed. Beyond Boundaries: Understanding, Translation, and Anthropological Discourse. Providence, Berg, pp. 210-230.

JAMES, Clifford and George E. MARCUS, eds. (1986). Writing Culture: The Poetics and Politics of Ethnography. Berkeley, University of California Press. 
JORDAN, Shirley Ann (2002)."Ethnographic Encounters:The Processes of Cultural Translation." Language and Intercultural Communication, 2, 2, pp. 96-110.

LIENHARDT, Godfrey (1954). "Modes of Thought.” In E.E. EvansPritchard et al. The Institutions of Primitive Society: A Series of Broadcast Talks. Oxford, Basil Blackwell, pp. 95-107.

LONGINOVIC, Tomislav Z. (2002). "Fearful Asymmetries: A Manifesto of Cultural Translation." Journal of the Midwest Modern Language Association, 35, 2, pp. 5-12.

LONGINOVIC, Tomislav and Boris BUDEN (2008). "The Answer is in Translation." Transversal-EIPCP Multilingual Webjournal. [eipcnet/transversal/0908/longinovic-buden/en]. NIRANJANA, Tejaswini (1992). Siting Translation: History, PostStructuralism, and the Colonial Context. Berkeley, University of California Press.

OGRODNICK, Margaret (2010). "Feminism, Democracy, and the Limits of Diversity: Reflections from Canada." North Dakota Quarterly, 77, 1, pp. 32-50.

RIBEIRO, António Sousa (2004). "The Reason of Borders or a Border Reason? Translation as a Metaphor for Our Times." Eurozine, 8 January. [www.eurozine.com/pdf/2004-01-08-ribeiro-en.pdf].

RUSHDIE, Salman (1988). The Satanic Verses. New York, Picador.

SAID, Edward (1989). "Representing the Colonized: Anthropology's Interlocutors." Critical Inquiry, 15, pp. 205-225.

SHARIFY-FUNK, Meena (2011). "Governing the Face Veil: Quebec's Bill 94 and the Transnational Politics of Women's Identity." International Journal of Canadian Studies, 43, pp. 135-163.

SIMON, Sherry (1995). "La culture transnationale en question: visées de la traduction chez Homi Bhabha et Gayatri Spivak." Études françaises, 31, 3, pp. 43-57.

SIMON, Sherry (1997). "Translation, Postcolonialism and Cultural Studies.” Meta, 42, 2, pp. 462-477.

Simone de Beauvoir Institute (2010). Simone de Beauvoir Institute's Statement in Response to Bill 94. [wsdb.concordia.ca/documents/ SdBI2010Bill94-bilingualresponse.pdf].

STEINER, George (1975). After Babel: Aspects of Language and Translation. New York, Oxford University Press.

TRIVEDI, Harish (2007). "Translating Culture vs. Cultural Translation.” In P. St-Pierre and P.C. Kar, eds. In Translation. Reflections, Refractions, Transformations. Amsterdam/Philadelphia, John Benjamins, pp. 277-287. 
VENUTI, Lawrence (2003). "Translating Derrida on Translation: Relevance and Disciplinary Resistance." Yale Journal of Criticism, 16, 2, pp. 237-262.

Kyle Conway

University of North Dakota

Department of English

276 Centennial Drive, Stop 7209

Grand Forks, ND 58202 USA

kyle.conway@und.edu 